\title{
Urban Democracy and the Local Trap
}

\author{
Mark Purcell \\ [Paper first received, June 2005; in final form, November 2005]
}

Summary. This paper argues against the local trap-the tendency to assume that the local scale is preferable to other scales. The local trap is an important problem in the recent explosion of research on urban democracy and citizenship. The paper highlights one strain of that literature, the work on 'the right to the city'. It is argued that the right to the city is highly susceptible to the local trap, although it is not inherently so. As we continue to search for innovative new ideas like the right to the city that can help to democratise cities, it is critical to think carefully and strategically about scale.

\section{Introduction}

Recent work in political economy has paid extensive attention to the processes of neo-liberal globalisation (for example, Yaghmaian, 1998; Kelly, 1999; Peck, 2001; Brenner and Theodore, 2002; Gough, 2002; Leitner and Sheppard, 2002; Smith, 2002; Tickell and Peck, 2003) and there has been particular interest in the way these processes have affected urban space and urban governance (Jessop, 2002; Jones and Ward, 2002; Keil, 2002; Kipfer and Keil, 2002; MacLeod, 2002; Swyngedouw et al., 2002; Wu, 2002). Much of this work concludes that one consequence of urban neo-liberalisation has been that capital has more power to produce urban space with respect to 'the public', however, defined. Thus there is a pervasive (if not thoroughly examined) sense that urban neo-liberalisation threatens urban democracy. Partly as a result of this literature, there has been much interest recently in new ways to democratise the decisions that produce urban space (Berry et al., 1993; Hipsher, 1996; Brown, 1997;
Beauregard and Bounds, 2000; Brodie, 2000; Amin and Thrift, 2002; Friedmann, 2002; Fung and Wright, 2003a, 2003b).

This paper fully supports this new attention to democracy and citizenship in cities. However, my goal is to present a cautionary argument that I hope can help us to move forward as effectively as possible. As we discover, narrate and invent new ideas about democracy and citizenship in cities, it is critical to avoid what I call the local trap, in which the local scale is assumed to be inherently more democratic than other scales. As I will try to make clear, the local trap is extremely prevalent, especially in leftist academia and activism. It appears to be almost habit among many traditions to prefer a priori the local scale. The paper argues against the local trap. It contends that it is dangerous to make any assumption about any scale. Scales are not independent entities with pre-given characteristics. Instead, they are socially constructed strategies to achieve particular ends. Therefore, any scale or scalar strategy can result in any outcome. Localisation can lead 
to a more democratic city, or a less democratic one. All depends on the agenda of those empowered by a given scalar strategy. The paper does not reject the local scale, therefore; it argues that we should reject the local trap.

The paper argues against the local trap in three ways. First, I develop a theoretical claim using a social-production argument from scale theory in geography. Secondly, I review one particular subset of the urban democracy literature, that concerned with 'the right to the city', to illustrate how the local trap can tempt democrats and how it can create important democratic problems. Thirdly, I present a brief case study from Seattle that explores these issues in the context of an empirical example. The paper concludes by rejecting the need for a particularly urban democracy, without abandoning the quest for greater democracy in cities. Before I turn to my argument against the local trap, I take a moment to sketch the neo-liberal context that has made it imperative to pursue greater democracy in cities.

\section{Neo-liberal Globalisation and Democracy}

The recent interest in urban democracy and citizenship arises in part out of a widespread concern about neo-liberal globalisation: the increasing functional integration of all people and places in the world into a single, laissezfaire and capitalist political-economy. The concern is that neo-liberal globalisation is undermining democracy (Falk, 2000; Murphy, 2000; Castles, 2001; Goodhart, 2001). It is important to be clear at the outset that 'democracy' has many interpretations. The dominant interpretation of liberal democracy, for example, can be seen as compatible with economic globalisation, as when neo-liberals advocate the spread of the formal institutions of liberal democracy as part of their vision. However, from other perspectives, such as participatory, social, deliberative or radical democracy, neo-liberalisation produces important democratic problems. Social democrats decry the erosion of state policies of social insurance and economic redistribution and the associated growth of material inequality at all scales. These economic shifts have meant that the very social and material basis for greater political equality - central to the very idea of [social] democracyhas been undermined in many countries (Gill, 1996, p. 215).

Moreover, for deliberative democrats like Dryzek (1996), the neo-liberal emphasis of the free market has promoted consumer identities over citizen identities. Rather than deliberative democracy's ideal of citizens seeking the common good, neo-liberalism values what Walter Parker (2003), resurrecting the term's original meaning, calls 'idiots'-individuals myopically pursuing only their self-interest.

In addition to these more general antidemocratic trends, we see also the increasing influence of institutions designed to be off limits to democratic control, such as central banks, WTO, IMF and the World Bank (Dryzek, 1996, p. 6). As participatory democrats like Fung and Wright argue

Deregulation, privatisation, reduction of social services, and curtailments of state spending have been the watchwords, rather than participation, greater responsiveness, more creative and effective forms of democratic state intervention (Fung and Wright, 2003b, p. 4).

The way to resist neo-liberalisation, this line of argument contends, is to democratise decisions "by setting up participatory instruments of nonelite empowerment and public accountability both inside and outside the state" (Nylen, 2003, p. 120). Here, for example, the 'participatory budgeting' experiment in Brazil has been an important model for critical reflection (Baiocchi, 2003).

Many in urban studies have applied this more general argument about neo-liberal globalisation specifically to urban governance (Jessop, 1997; Brenner, 1999; MacLeod and Goodwin, 1999). This large body of research demonstrates that for cities the need to remain globally competitive increasingly dictates urban policy decisions, narrowing the options open to decision-makers (Dryzek, 1996). As a result, urban governing institutions have been restructured so that they 
are better able to respond to the needs of capital. They are becoming less a democratic forum for citizens to make decisions and more a tool to ensure that the area competes effectively for capital investment. This shift is a problem in the eyes of all democratic traditions, even the liberal one. In this climate, democratic decision-making is seen as slow, messy, inefficient and less likely to produce the kind of tax reductions, infrastructure spending, insurance reforms and business deregulation that attract and keep capital in an increasingly competitive global economy. As a result, governing institutions are being increasingly 'streamlined' so they are less accountable to the public (Hoggett, 1987). Thus institutions like public-private partnerships, appointed competitiveness councils and quasi-public agencies are increasingly making decisions that were formerly made by elected officials directly accountable to the public. In short, this literature finds that the decisions that shape the city are increasingly being transferred away from democratic citizens and towards corporations (Keating, 1991; Brownhill et al., 1996; Peck, 1998; Ward, 2000; Tickell and Peck, 2003).

To be sure, this dynamic is variable across time, space and policy area. Increasingly, neo-liberal policies have even been responding to their democratic deficits by advocating more democratic decisions. ${ }^{1}$ I discuss this dynamic in more detail elsewhere (Purcell, 2004). But it is not the point of this paper to defend fully the thesis that neo-liberalisation threatens democracy. Rather, following the literature above, I set as the background to my discussion the premise that the structural trend is for the neo-liberal project to move urban governance away from democratic decision-making.

\section{Urban Citizenship, Democracy and the Right to the City}

The growing democratic problems that neoliberalisation has produced have been an important impetus for an explosion of research on the theme of democracy (Held, 1995; Axtman, 1996; Benhabib, 1996; Brown, 1997; Mouffe, 1999; Young, 2000; Goodhart, 2001;
Decker, 2002). A closely related theme has been studies of citizenship (Hammar, 1990; Smith, 1995; Yuval-Davis, 1997; Linklater, 1998; Soysal, 1999; Mitchell, 2001). Many authors have focused specifically on how these themes play out in cities (Staeheli, 1994; Flyvbjerg, 1998; Bender, 1999; Beauregard and Bounds, 2000; Isin, 2000b; Sassen, 2000; Turner, 2000; McGuirk, 2001; Swyngedouw et al., 2002; Secor, 2003). A small but growing sub-section of the urban work has become fascinated with the concept of 'the right to the city' as one important principle that can inform our thinking on democracy and citizenship in the city (Friedmann, 1995; Rights to the City, 1998, 2002; Holston, 1999; Dikec, 2001; Souza, 2001; Mitchell, 2003; Purcell, 2003; Staeheli, 2003).

I will focus my argument on the right to the city as a way to illustrate in depth the problem of the local trap, but I mean my caution against the local trap to apply as a theoretical principle to the entire literature on urban democracy and citizenship. The work on the right to the city has introduced an exciting new set of ideas into the debate. However, very little of this work develops the concept explicitly (Purcell, 2002). One important problem with this lack of engagement is that, left unexamined, the right to the city leads easily into the local trap. It entices us to prioritise the interests of local residents over wider publics. As we respond to urban neo-liberalisation by developing new ideas and practices of democracy in the city, it is critical to be aware of and to avoid the local trap, because it presents an important danger to both democracy and social justice. In order to discuss the relationship between urban democracy and the local trap more fully, I start by developing a better idea of just what the local trap is and what it looks like in academic research.

\section{The Local Trap}

The local trap was first named and critiqued by Brown and Purcell in the context of the development studies literature (Brown and Purcell, 2005; Purcell and Brown, 2005). It refers to the tendency of researchers and 
activists to assume something inherent about the local scale. The local trap equates the local with 'the good'; it is preferred presumptively over non-local scales. What is defined as good can vary widely. In the democracy literature, of course, democratisation is the primary good. But locally trapped research also desires more sustainable, just or culturally diverse cities. The manifestations of the local trap vary from positive assertions that the local is preferable to passive and often unconscious assumptions. These assumptions usually conflate the local as a strategy with particular goals, such as the good outcomes just mentioned.

The local trap is a pervasive problem on the left, in both academia and activism. ${ }^{2}$ It ranges beyond the work on urban democracy and citizenship. For example, my own work with colleagues has explored the problem of the local trap in both international development studies and urban food systems (Born and Purcell, forthcoming). In international development studies, a leading alternative to the neoliberal 'Washington consensus' has been a call to democratise development decisions. This alternative, preferable though it may be to the neo-liberal hegemony, frequently falls into the local trap. The assumption is that localising decision-making will democratise it and that democratisation will result in greater social justice and ecological sustainability (for a more detailed examination, see Brown and Purcell, 2005). This logical string involves numerous assumptions that are extremely common in the literature on environment and development. First, localisation is conflated with democratisation, even though localisation can just as easily lead to tyranny and oppression (as with states' rights and slavery in the US South). Secondly, 'local people' are conflated with 'the people' of democracy's popular sovereignty, even though 'the people' can be (and have been) defined at a range of scales. Thirdly, 'community' is commonly conflated with 'local-scale community', even though communities exist at all scales. Fourthly, and following from the assumptions above, local 'communitybased development,' is then conflated with 'participatory development' even though local-scale community control does not necessarily lead towards greater popular participation. And fifthly, the modifier 'local' is regularly used to stand in for more specific ideas such as 'indigenous', 'poor', 'rural', 'weak', or 'traditional', even though there is nothing essentially local about any of these categories (for a detailed literature review of the local trap in development studies, see Purcell and Brown, 2005).

Similarly, activists and academics who are involved with food systems and security in the US and Britain often fall into the local trap (Born and Purcell, forthcoming). Here, a dual conflation occurs. The capitalist, corporate, industrial food system is conflated with its most extensive of operation, which is global. Because a core value of the literature is to oppose this conventional food system, many are led to assume that any global-scale food system is inherently undesirable. Many assume that there is something about the globality of the dominant food system (rather than its capitalism or industrialism or corporatism) that is problematic. As a consequence, localscale food systems, since they are not global, are assumed to be inherently desirable. Local food is conflated with just organic, sustainable, secure, fresh, or healthy food.

The same kind of problem is apparent in recent studies of urban democracy and citizenship. The very notion of a particularly urban citizenship or democracy creates (or perhaps reflects) an inclination to privilege more local scales (in the sense that the urban is more local than the national or the global). This inclination is merely a tendency, not a logical necessity. Examining urban citizenship or democracy can be the result of an empirical focus rather than a political preference. Nevertheless, the literature on urban citizenship and democracy is marked by the local trap in important ways. To be sure, the degree to which authors are conscious of the question of scale varies significantly throughout the literature. Some make a positive case for preferring the local scale, some do so latently and some are beginning to grapple with the empirical fact that local-scale 
arrangements do not always result in more democratic or more just outcomes. None, to my knowledge, offers a theoretical solution to the local trap by starting explicitly from the assumption that there is nothing inherent about scale, a solution I develop below.

The local trap in the urban democracy literature is founded on the assumption that devolution of authority will produce greater democracy. It is assumed that the more localised governing institutions are, the more democratic they will be. More specifically, the assumption is that the more autonomy local people have over their local urban area, the more democratic and just decisions about that space will be. Again, the force with which this argument is articulated varies from person to person. This tradition includes research on democracy and citizenship at the neighbourhood level (Berry et al., 1993; Fung, 2004), on 'community-based' development and planning (Fainstein and Fainstein, 1995; Mesch and Schwirian, 1996; Greenberg, 1999; McNulty, 1999; Gittell et al., 2000; Green and Haines, 2001; Wells, 2002; Murphy and Cunningham, 2003; Smock, 2003; Diers, 2004) and on governing institutions more generally (Council of Europe, 1985; UNDESA, 1992; Pratchett, 1999, 2004; Weir and Beetham, 1999; Madon and Sahay, 2000; Aigner et al., 2001; Hambleton et al., 2003; Latendresse, 2004; Speller and Ravenscroft, 2005). While some have begun to question if localised decision-making is necessarily good (Peterman, 1999; Mohan and Stokke, 2000; Boudreau, 2003), the prevailing wisdom follows Latendresse's (2004, p. 40) logic about Montreal, that "by decentralizing power to the boroughs, the Montréal megacity created some of the necessary conditions for a greater democratisation of urban life". The assumption that decentralisation is necessary for democratisation is the essence of the local trap.

In terms of the local trap, the community development literature is perhaps the most worrisome tradition. As in the international development literature, this body of work routinely assumes community to mean a very local-scale group, often no larger than a neighbourhood. The prevailing sensibility is that communities should control their own destiny and so decision-making should be localised as much as possible. Green and Haynes, for example, argue that

a key element [of community development] is the allocation of development decisions to the local level, where relationships between economic development, the environment, and social needs are most visible (Green and Haynes, 2001, p. 6).

Chaskin and Abunimah note two important convictions in the community development tradition

One is a philosophical belief in the democratic process and its appropriate connection to local associational action; the other is a pragmatic belief in the ability of decentralized approaches to provide more connected, responsive, and co-ordinated strategic action. Combined, these tenets reflect an adherence to a Tocquevillean vision of locally based collective action and a belief in neighbourhoods as real and potential units of such action (Chaskin and Abunimah, 1999, p. 60).

From an economic perspective, a similar tendency applies in the literature-as with the pervasive concern for capturing wealth in the 'local economy' (Murphy and Cunningham, 2003). This concern is especially prevalent outside academia, as with groups such as the Institute for Local Self-Reliance, which advocates maximal self-sufficiency for local economies.

A more sophisticated but nonetheless problematic example is the emerging agenda associated with empowered participatory governance (EPG). Fung and Wright lay out three 'design properties' for EPG, the first of which is 'devolution'.

Since empowered participatory governance targets problems and solicits participation localized in both issue and geographical space, its institutional reality requires the commensurate reorganization of the state apparatus. It entails the administrative and 
political devolution of power to local action units (Fung and Wright, 2003b, p. 20).

Fung and Wright are not naïve, however, and do see the potential for problems that local units cannot address by themselves. Nevertheless, their insistence on devolution to localscale units represents an assertion that democratisation requires localisation. Their tendency towards the local derives in an important way from their association with a 'participatory' model of democracy. More generally, the emphasis on decentralisation in the urban democracy literature is partly heir to the normative theory of participatory democracy associated with authors like Pateman (1970), Barber (2004), Mansbridge (1983) and Putnam (1993). Participatory democrats draw ultimately on Aristotle to argue that people realise their full political and human potential only by participating actively in political decisions. They stress the need for face-to-face interaction, argumentation and negotiation so that people can develop most fully as citizens. Therefore, they largely oppose representative democracy because it makes the direct participation of citizens much less necessary. Clearly, localscale communities are much more amenable to this kind of direct, participatory democracy. A more representative model of democracy is a practical necessity for communities too large for effective face-to-face interaction. Thus the participatory tradition in democratic theory injects a strong tendency to assume that the local is more democratic than other scales. Buttressing this tendency is the work of 'associative' democrats such as Cohen and Rogers (1995) and Matthews (1989) who regard the devolution of power to the local scale as a way to invigorate democracy (Cunningham, 2001, p. 136). Charles Lummis, perhaps the most eloquent writer in this tradition, is also the most strident

'Democratic centralism' is an expression like 'hot ice' or 'diverse unity'; just because you can say the words doesn't prove that they mean something. In general, democracy depends on localism: the local areas are where the people live.
Democracy doesn't mean putting power some place other than where people are (Lummis, 1997, p. 18).

Those on the right are also susceptible to the local trap. The recent attempt by conservative home-owners in the San Fernando Valley to secede from the City of Los Angeles was justified in part by the argument that secession would give the Valley local control and would therefore be more democratic (Purcell, 2000). Secession apologists have repeated this specious claim (Hasselhoff, 2002). To say the least, giving greater decision-making control over their local space to a relatively Whiter and more affluent section of the city is not the greatest guarantee of either democracy or social justice. In the leftist community development literature, the great irony of the preference for the local scale is that it plays into the hands of the neo-liberal agenda. The Republican-led withdrawal of federal-government funding from urban development has shifted the financial and organisational burden of community development onto locally based NGOs. Devolution, decentralisation and local self-reliance are exactly the vision that Nixon, Reagan, Thatcher and other neo-liberal champions have advocated (Peterman, 1999).

As I discussed earlier, part of the neoliberal agenda is for the state to increasingly offload responsibility for social provisions onto local authorities and community groups. Neo-liberal apologists routinely justify offloading by arguing that it augments local control and is therefore more democratic. The 'new localism' of the current Labour government in Britain operates along these lines (Deas and Ward, 2000; Pratchett, 2004). Peterman sums up the US case

If neither the government nor the private sector were willing to be the engines of reinvestment, then, it was argued, the only way to bring about neighbourhood revitalization was for the community itself to take on the tasks of reinvestment and development (Peterman, 1999, p. 49). 
In many ways, community-based development is a scrambling response to the massive disinvestment in communities that neoliberalisation has wrought. It is very dangerous to uncritically assume, with the neo-liberals, that the resulting localisation of decision-making is desirable. For example, one of the cases that Fung celebrates in his EPG work is the democratisation that took place in Chicago as a result of a programme of community policing (Fung and Wright, 2003b; Fung, 2004). Fung suggests that community policing programmes took control over neighbourhood surveillance away from the autocratic and unresponsive police department and put it increasingly in the hands of the community. However, similarly detailed field research by Steve Herbert suggests a less rosy picture. He argues that community groups feel they are being asked to do work the state should be doing. In Herbert's research, local communities feel overextended and burdened by neo-liberal offloading, not empowered (Herbert, 2005). Similar problems arose in the celebrated case of neighbourhood planning in Seattle. Those active in the process expressed concern that city government dumped responsibility for public projects onto neighbourhood NGOs. One activist felt that the city was withdrawing from the neighbourhoods, that they "dumped a bunch of stuff back in our lap" (Ceraso, 1999).

These empirical concerns begin to reveal some problems with the local trap. Before I develop my case against the local trap further, it is worthwhile to suggest in the abstract some general problems that follow from its assumptions. The first is the most basic: the assumption that local is desirable is not always true. Mounting case study evidence from all of the above traditions suggests that local-scale arrangements lead to a variety of outcomes, only some of them good. Secondly, the local trap treats localisation as an end in itself (since it is conflated with the good), rather than as a means to an end such as democracy, justice or sustainability. Activists and academics pursuing localisation can therefore be distracted from pursuing their real goal, whatever that might be. In the worst case, this distraction will subvert the goal, as when someone who desires greater democracy pursues localisation that results in a more oligarchical decisionmaking. Thirdly, the local trap obscures other scalar options that might be more effective in achieving a desired outcome. For example, assuming that localisation necessarily leads to more sustainable environmental decisions will occlude the option of, say, a European-Union-wide law that mandates more sustainable agricultural practices in member-countries (Goodman, 2003).

\section{The Case against the Local Trap}

\section{Theoretical}

My theoretical case against the local trap draws on the burgeoning scale literature in political and economic geography. The key theoretical principle in this literature is that scale is socially constructed. While this principle is widely held in the literature, it is best articulated by Sallie Marston's (2000) often-cited article. The argument is that all scales are socially produced through struggle (Delaney and Leitner, 1997; Kelly, 1997). Therefore, the particular qualities of a given scale, such as its extent, its function or its relationships to other scales, are not eternal or ontologically given (Smith, 1992, 1993). Rather, they are contingent: they will result from particular struggles among particular actors in particular times and places. While the principle of social construction has become almost a truism in the social sciences, if we take it seriously with respect to scale we must conclude in general that there is nothing inherent about any scale. We cannot assume $a$ priori anything about the characteristics of a particular scale or scalar arrangement. We cannot assume that localised decisionmaking structures are inherently more democratic than global ones. Moreover, and perhaps more unsettlingly, we cannot even assume that a balanced multiscale arrangement is preferable to a single-scale one. That is, we cannot say before the fact that a federal scalar structure involving local, 
regional, national and global bodies in decision-making is any more democratic than one in which all decisions are made by, say, a national-scale entity.

From the principle of social construction, it follows that the outcomes of a particular scalar arrangement are contingent. They depend on the particular agendas that are empowered by the scalar arrangement. Localising control over space can produce greater democracy or not, or greater social justice or not, depending on who is empowered by the localisation. And there is no inherent or even tendential link between the agendas of localscale groups and the agenda of democracy or that of social justice. The same is true of regional-scale groups, or national-scale ones. Because scale is not an ontological entity with particular properties, it is better seen, as Erik Swyngedouw has insisted, as a strategy, as a way to achieve a particular end (Swyngedouw, 1997a). What this end will be will vary according to who is pursuing it. The theoretical premise of social construction thus serves as a reliable corrective for those tempted into the local trap.

Another important insight of this literature, one that both supports and complicates the first, is that geographical scale is both fluid and fixed. If scales are socially produced through political struggle, then scales and scalar arrangements are fluid in the sense that they are always in historical motion. Swyngedouw (1997b; 2000), for example, argues particularly strongly that scale is fluid and that researchers have tended erroneously to think of scales as fixed and given. They have assumed that each scale has both a fixed extent and a preset function in the global political economy. This assumption has led us to treat scale as a latent variable instead of an active object of inquiry. It has prevented researchers from perceiving how scales are being continually reorganised.

Despite this emphasis on fluidity, however, others stress that the malleability is never total. Scales and scalar arrangements can also be fixed into relatively enduring and hegemonic structures for certain periods of time. Of course, these characteristics and process are only temporarily (not inherently) associated with a particular scale and each scalar configuration must be continually reproduced through a political project. Even though we should expect a given scalar configuration-such as national-scale state sovereignty-to be challenged and eventually overcome by other projects that imagine sovereignty at other scales, nevertheless a dominantly national-scale sovereignty can become hegemonic for a time and this hegemony can have real and important effects on the exercise of political power (Purcell, 2003). In this sense, scale is not only fluid, it is also fixed.

This partial fixity, of course, can create the conditions for a measure of 'structured coherence' in a particular context that can tempt actors into the local trap (Harvey, 1982). For example, if in a given case neo-liberal interests have successfully used a strategy of nationalisation to pursue their goals, those resisting neo-liberalism might come to associate the national scale with the neo-liberal agenda and the local scale with resistance. In that case, such scalar associations may become a workable shorthand for action and the assumptions of the local trap can seem to match reality for a time. However, even in such cases, the local trap remains dangerous. First, structured coherence is never total and so, even if scalar assumptions tend to be valid in a particular case, they will never be always valid. Secondly, it is politically debilitating to assume an equivalence between a scalar strategy (nationalisation) and an agenda (neo-liberalism), because it cedes that scalar strategy to the opposition. Even when neo-liberals have pursued a nationalisation strategy, there is no reason why activists cannot also pursue an alternative nationalisation strategy to resist. Lastly, the principle of social construction reminds us that such structured coherence is always temporary. Even when scalar assumptions tend to 'work' under conditions of structured coherence, they will always work temporarily. Any practical validity a scalar assumption might have is always being destabilised and will soon be lost. Therefore, it remains imperative that all 
assumptions about scale be continually subjected to critical re-evaluation.

A last insight of the scale literature is that scale is a fundamentally relational concept (Agnew, 1997; Howitt, 1998; Kelly, 1999). That is, the very idea of scale necessarily implies a set of interscalar relationships. A 'local' scale, for example, only has meaning in relation to other, non-local scales. Each scale is therefore inseparably defined by and linked to others. The particular relationships among scales are the product of social production. The principle of national sovereignty advocates the dominance of the national-scale state over other state scales. It establishes a particular relationship between the national and other scales. Any move towards localisation of sovereignty, conversely, advocates a new relationship between local and national/ regional scales, as power devolves to local areas. Neil Brenner (2001) is particularly insistent on the relational qualities of scale. He calls for analyses that focus on the "shifting organisational, strategic, discursive, and symbolic relationships between a range of intertwined geographical scales" (Brenner, 2001, p. 20). Therefore, analyses of scale must specifically interrogate the changing interrelationships among the various scales.

If we were to tie these three theoretical principles together into a coherent methodological approach, we might say that descriptive research on scale should interrogate how the interrelationships among scales are continually fixed, struggled over and reworked by particular social actors pursuing specific political, social, economic and ecological goals. Normative research should critically analyse why a particular rescaling (such as localisation) is better than other rescaling strategies (globalisation/nationalisation/regionalisation) for achieving specific goals (such as democratisation) and these goals should be clearly articulated and distinguished from the scalar strategy used to pursue them.

If we follow the scale literature and adopt these theoretical principles, the local trap becomes untenable. If there is nothing inherent about any particular scale, then in the long-term we cannot associate a particular scale with a particular goal. We cannot assume that localisation of decision-making will necessarily result in democratisation. Instead, localisation should raise no a priori assumptions; it points to an on-going struggle among competing interests. It invites inquiry to discover what actors and agendas brought about and were empowered by localisation. It is those actors and agendas that produce outcomes, not the scales through which the agendas were realised.

\section{The Right to the City}

One strain of the new work on urban citizenship and democracy evokes the notion of 'the right to the city'. This concept provides an important illustration of how the local trap can tempt us. Many in academia have begun to explore 'the right to the city' as a promising possibility (Isin, 1996; Soja, 1996, 2000; Rights to the City, 1998, 2002; Sandercock, 1998; Holston, 1999; Holston and Appadurai, 1999; Isin and Wood, 1999; Isin, 2000a; Sassen, 2000). Beyond academia, the term is also gaining greater attention. To name just a few examples, it is being evoked in conflicts over housing (Olds, 1998; Grant Building Tenants Association, 2001), against patriarchal cities (UNCHS, 2001; City and Shelter et al., n.d.), for participatory planning (Daniel, 2001) and against social exclusion in cities more generally (Buroni, 1998; Cities for Human Rights, 1998; Worldwide Conference on the Right to Cities Free from Discrimination and Inequality, 2002).

Unfortunately, however, few in or out of academia have offered a detailed exposition of just what the right to the city would entail and they have not developed what benefits or detriments it might have for the enfranchisement of urban residents. To be clear, this work is innovative, stimulating and welcome. However, it falls short of a careful exposition and evaluation of the right to the city idea. We lack a comprehensive explanation of what the right to the city is or how it would challenge, compliment or replace current rights and rights claims. For example, a recent conference in Rome entirely 
devoted to right(s) to the city was full of excellent papers. However, virtually all of them failed to discuss the idea in detail (Rights to the City, 2002). Moreover, each paper seemed to take it as a given that the right to the city was desirable.

The few who have explored the concept in greater depth have all done so by drawing explicitly on the formulation of Henri Lefebvre (Dikec, 2001; Mitchell, 2003; Purcell, 2003). I begin this discussion by sketching a Lefebvrian exposition of the idea. In doing so, I certainly do not wish to say that a Lefebvrian formulation is the only acceptable way to conceive of the right to the city, or that we need a unified conception at all. Rather, I return to Lefebvre's initial idea as one starting-point for a more explicit delineation of the right to the city. The Lefebvrian conception, I argue, has the potential to lead scholars and activists into the local trap.

Lefebvre's conception of the right to the city is mostly articulated in two short works, The Right to the City and Space and Politics (Lefebvre, 1968, 1973, 1991a, 1996). In these volumes, he argues for profoundly reworking both the social relations of capitalism and the current structure of decisionmaking in cities. His right to the city is a call for a radical restructuring of social, political and economic relations, both in the city and beyond. One key to this radical nature is that Lefebvre's right to the city reframes decision-making in cities: instead of limiting democratic decision-making to state decisions, he imagines it to apply to any decision that contributes to the production of urban space. This shift differentiates the right to the city clearly from present forms of democratic enfranchisement in liberal democracies, which revolve predominantly around the structures, policies and decisions of the formal state. Liberal-democratic citizens (whose formal citizenship status is based on nationality) have an institutionalised voice in the decisions of the state and they therefore have some indirect control over any social process the state can influence. By contrast, the right to the city imagines people to be enfranchised with respect to all decisions that produce urban space. That simple change radically expands the scope of democratic enfranchisement and citizenship beyond the state structure. Many of the decisions that produce urban space are made within the state, but many more of them are made outside it. The investment decisions of firms, for example, would fall within the purview of the right to the city because such decisions play a critical role in producing urban space.

But what kind of agenda does Lefebvre hope will result from this transformed enfranchisement? The right to the city stresses that the city must be produced so that it meets the needs of the users of urban space, not its owners. Hence, he stresses the key role that urban inhabitants must play in making decisions. He imagines a far-reaching claim to shift control away from capital and the state and towards urban inhabitants. For Lefebvre, one lays claim to the right to the city by inhabiting the city. Through their everyday routines and rhythms of life in the city, inhabitants come both to depend on and truly to understand urban space. Lefebvre celebrates these everyday routines; he idealises the urban inhabitant as the legitimate steward of urban space. The right to the city is designed to further the interests "of the whole society and firstly of all those who inhabit" (Lefebvre, 1996, p. 158). He argues that the right to the city

should modify, concretize and make more practical the rights of the citizen as an urban dweller (citadin) and user of multiple services. It would affirm, on the one hand, the right of users to make known their ideas on the space and time of their activities in the urban area; it would also cover the right to the use of the center, a privileged place, instead of being dispersed and stuck into ghettos (for workers, immigrants, the 'marginal' and even for the 'privileged') (Lefebvre, 1991a; translated in Kofman and Lebas, 1996, p. 34).

Lefebvre is clear that the decision-making role of inhabitants must be central, but he is not explicit about what that centrality would 
mean. He does not clearly say decisions that produce urban space should be made entirely by inhabitants. But it is clear that the role inhabitants play must be central and direct. In playing that central role, inhabitants would ensure their right to physically access, occupy and use urban space. They have the right to "full and complete usage" of urban space in the course of everyday life (Lefebvre, 1996, p. 179). This claim of course stands in direct opposition to the capitalist notion of property rights so central to current urban decision-making.

Lefebvre did not write expansively on the question of scale and his work on the right to the city is no exception. Lefebvre's right to the city does not explicitly fall into the local trap. Indeed, in other writings (and to a lesser extent in the Right to the City itself) his vision of the urban is expansive, not parochial (Lefebvre, 1991a, 2003). If we were to contextualise Lefebvre's statements about the right to the city in a thorough exposition of his various other work, we might well produce something that effectively avoids the local trap. However, current work on the right to the city rarely even engages or cites Lefebvre's Right to the City; it is therefore unlikely to offer a subtle reading of his right to the city idea in the context of his other work. So, lacking such a contextualisation, for those who are currently advocating a right to the city it is only a very short step from privileging inhabitants to privileging local residents. This step is made more tempting because Lefebvre's notion of inhabitance as he develops it in the Right to the City and Space and Politics is expressly quotidian. It emphasises the routines and rhythms through which inhabitants engage the city. This emphasis on daily, concrete experience leads one to conceive of inhabitance and inhabitants in local terms, to see the right to the city as the right of local people to control what happens in their local space. This would mean that neighbourhood groups (not city-wide bodies) should decide how neighbourhood space is produced, since they most fully inhabit that space every day. Or, in a larger area, it could mean that city-wide inhabitants should control the production of space in their city, rather than decision-making bodies at wider scales (county, state, nation, etc.). This is precisely the manifestation of the local trap we see in the development studies literature, where many conflate local autonomy with greater democracy or justice (Purcell and Brown, 2005). It is important to reiterate that I am not saying that Lefebvre himself would have affirmed a locally trapped right to the city. In fact, the opposite is probably true. However, there is a clear danger that the right to the city idea, with or without reference to Lefebvre, can be mobilised in locally trapped ways. To develop how this might look in concrete terms, I offer a brief case study of local politics in Seattle.

\section{Empirical Illustration: Politics in Seattle}

Currently, the South Lake Union (SLU) area of Seattle is undergoing a significant redevelopment that exhibits many elements of the relationship between neo-liberalism and democracy I outline above. SLU has long been a fairly low-density mixture of warehouses, car dealerships, marine-commercial, light manufacturing and, in its Cascade subsection, residents with moderate incomes (see Figure 1). Recently, one of the city's largest real estate development firms, Vulcan, Inc., which is owned by Microsoft billionaire Paul Allen, purchased a significant portion of the property in the area (see Figure 2). Vulcan's project is multifaceted, but in large part it is driven by speculation that a small hub of biotechnology firms in the area will serve as a 'technopole' for the development of a global centre for biotechnology (Scott, 1993). Such biotechnology hubs are an increasingly common neo-liberal growth strategy (Larner, 2005). In the SLU case, the technopole would be supported by a number of biotechnology firms already operating in the area, as well as the University of Washington, which has a particular expertise in biotechnology research. The technopole vision is the expressed goal of both Seattle's mayor, Greg Nickels, and Washington's recently elected governor, Christine Gregoire. 


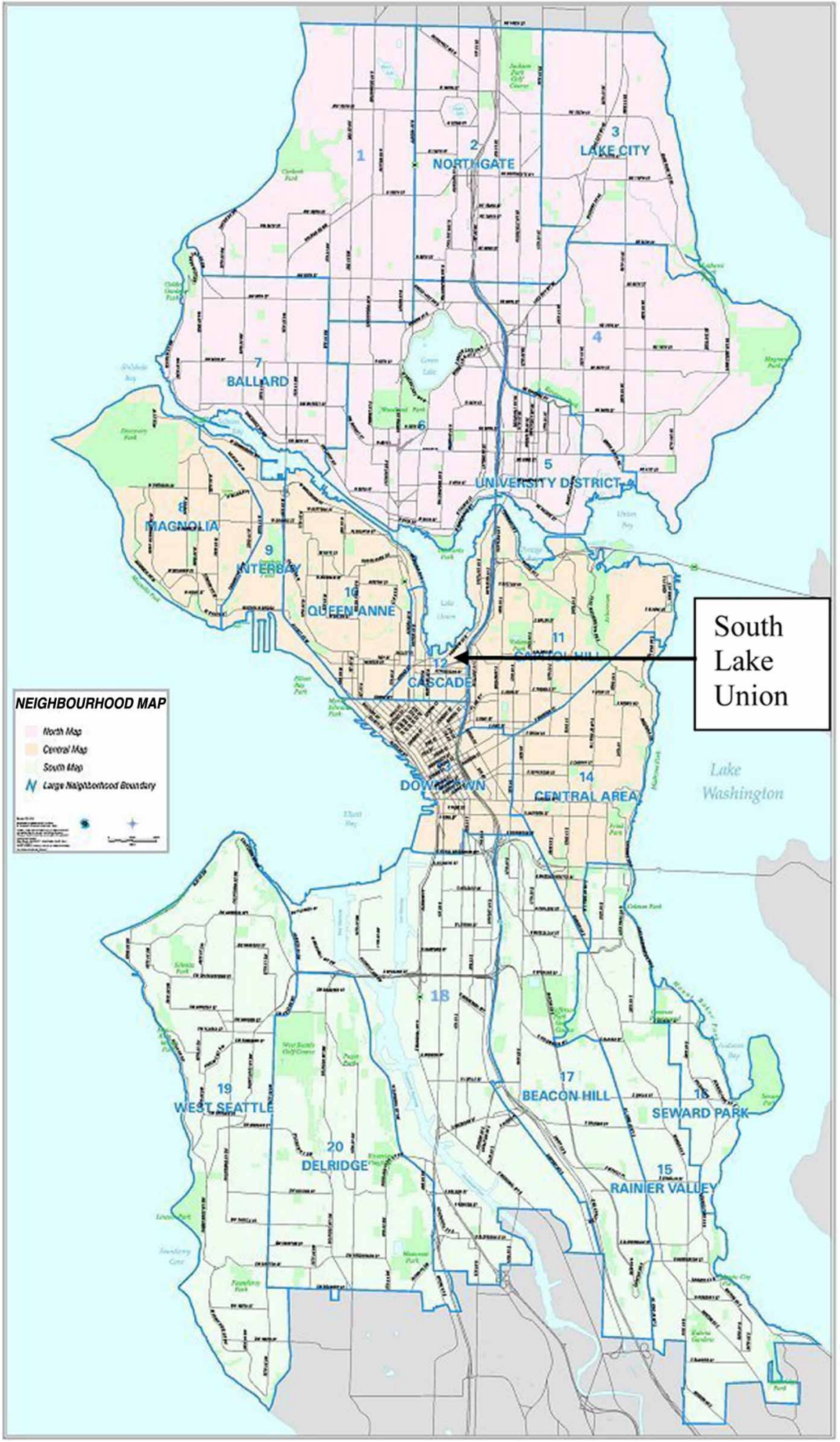

Figure 1. Seattle and South Lake Union. 


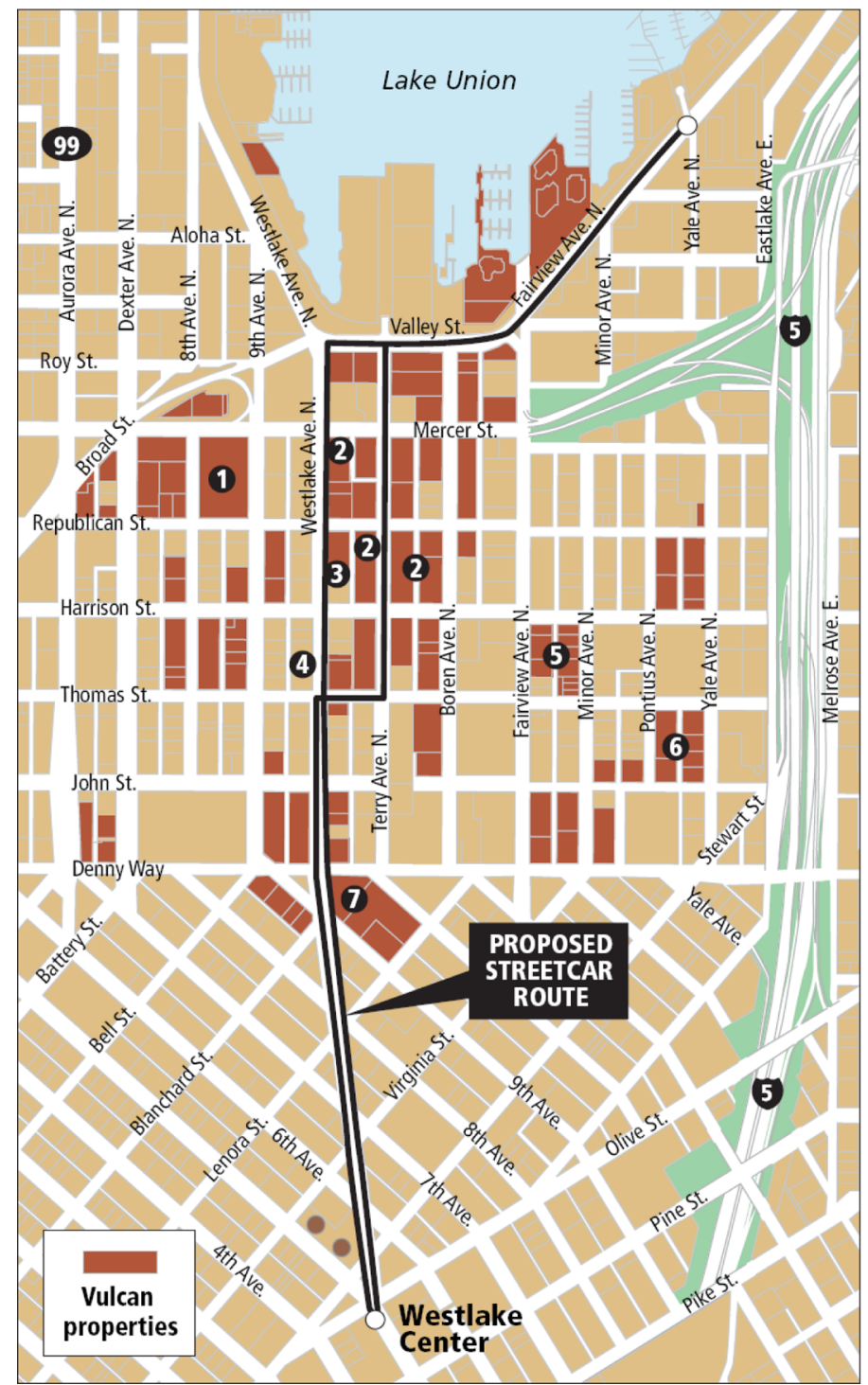

The Seattle City Council will consider more than a half-dozen proposals related to South Lake Union to make it easier to develop the neighbourhood into a biotechnology hub. Billionaire Paul Allen's Vulcan Company is leading the push. Allen owns 58 acres in South Lake Union, and Vulcan plans to build more than 10 million square feet of residential, office and commercial space.

\section{CURRENT VULCAN DEVELOPMENTS}

This year, companies have moved 550 employees into South Lake Union buildings owned by Vulcan.

(1) 815 Mercer St.: University of Washington plans to move about 300 employees into 105,000 square feet in the renovated Washington Natural Gas "Blue Flame" building in December. The building is leased by the university.

\section{Terry Ave: Rosetta} Inpharmatics/Merck moved about 300 employees into part of the Interurban Exchange complex owned by Vulcan.

(3) 428 Westlake Ave. N.: Proposed office building, to be occupied in part by CollinsWoerman Architecture.

4307 Westlake Ave. N.: Seattle Biomedical Research Institute moved in 170 employees; Children's Hospital brought 60 workers.

5301 Minor Ave. N: The 162-unit Alcyone apartment complex opened in May.

6223 Yale Ave. N.: Headquarters for NBBJ and Skanska. The development that will include 180 residential units, retail and office space.

(72200 Westlake Ave. N.: Commercial and residential complex anchored by Whole Foods and the Pan Pacific Hotel.

Figure 2. Vulcan Holdings in South Lake Union. Source: Mulady (2004b).

There is, in short, a convergence of agendas between the private sector and leading figures in municipal and state government. Some have implied the existence of corruption insofar as current Vulcan employees are former staffers for the Mayor and City Council (Mulady, 2004a). However, it is more accurate to say that the agendas of the City and Vulcan converge around the desire to create a biotechnology boom in SLU. This convergence has produced a shared strategy that has the City and Vulcan working closely together. Many of Vulcan's current holdings were bought from the City at a bargain rate. Then the City rezoned much of that land to make it more amenable to the biotechnology vision (and consequently more valuable to Vulcan). Currently, the City is moving to commit a significant amount of public money to improve the local infrastructure for biotechnology, further increasing the value of Vulcan's investment. Estimates 
vary as to the amount of this proposed public investment. The City suggests it is around $\$ 420000000$, while at least one activist counters it is closer to $\$ 1$ billion (Mulady, 2004b). To suggest somehow that graft or personal relationships are moving the city to line Vulcan's pockets is to miss the deep mutual benefit that both public and private sectors believe will result from a biotechnology hub. In essence, what has emerged is an informal but nevertheless strong public-private partnership, a common neo-liberal governance structure for promoting an economic growth agenda.

As part of the partnership's strategy, a clear narrative has been constructed to advocate the redevelopment of SLU. The narrative begins with the story of the fragile regional economy. Boeing, the region's aerospace anchor, is carrying out an on-going disinvestment that will deeply impact not only Boeing employees, but also the industry's many multipliers. Moreover, the recent dotcom bust has revealed the fragility of an economy dependent on the unreliable profitability of Internet firms. In terms of economic development, biotechnology is widely seen as 'the next big thing' and it is therefore the perfect insurance against the region's shaky economy. Referring to a powerful economic symbol in the local imagination, the Mayor promised in a 2003 press release that biotech will be "equivalent to another Microsoft". Buttressing this narrative of economic growth, another narrative constructs the South Lake Union area as 'empty', both in terms of residents and economic value. Only a few (marginal) people live in SLU, the narrative goes, and the businesses there are hardly central to the regional economy. Redevelopment in this empty area will therefore cause minimal disruption but produce maximum economic benefit. Together, these narratives lead inexorably to the conclusion that we must undertake a comprehensive redevelopment of SLU to create a biotechnology boom for the region.

These narratives are supported by the neoliberal narrative of global competitiveness. Because biotechnology is the hot new industry, many cities will compete to attract biotechnology investment. If Seattle wants to create a globally competitive hub, it cannot be indecisive. It has to be assertive. The city is famous for 'the Seattle Way' - an affinity for democratic process in which public decisions are extensively debated, far more so than in other cities. In this case, the narrative goes, the city cannot afford the luxury of the Seattle Way. Not only must we redevelop SLU, we must do so quickly, with minimal dithering, in a way that is most attractive to biotechnology capital. The informal partnership has taken precisely that tack: the process has been strikingly closed and insulated from public debate, especially in the context of the Seattle Way.

The right to the city immediately resists these narratives. It would offer a counter-narrative based on the assertion that SLU is not empty. According to the 2000 census, there are about 1500 residents in South Lake Union, mostly in the Cascade neighbourhood. They are mostly of low-to-moderate income. The area is also home to a number of social service agencies, mostly NGOs providing housing, drug and counselling services. The residents and the users of social services inhabit South Lake Union, living out their everyday routines and rhythms there. They both depend on and intimately understand SLU's space in a way that Vulcan, the City and the biotechnology firms never could. As the users of South Lake Union, Cascade residents should play a central role in deciding how its space is produced. The right to the city would thus be the foundation of a claim that would oppose any redevelopment that gentrifies the area and squeezes out residents of moderate income. It would not necessarily oppose a biotechnology hub, but it would mandate a careful consideration of how the redevelopment was carried out: how would the needs of current residents (especially low-income ones) be met? How would affordable housing be preserved? What jobs would the new hub offer inhabitants?

Against the neo-liberal instinct to sacrifice such questions on the altar of competitiveness, the right to the city demands these questions be central to redevelopment discourse. However, the right to the city can also urge 
us into the local trap. It encourages an emphasis on the rights of neighbourhood inhabitants. It thus could easily lead us to assume that local neighbourhood control over SLU redevelopment would be more democratic than control at a city-wide scale. It is more democratic, the right to the city might suggest, for those who inhabit the space of SLU, those who depend on it most and know it best, to decide its future. While this approach might meet the needs of SLU inhabitants, it may or may not result in a democratic or socially just outcome. For example, if a biotechnology boom were to create a significant number of living-wage jobs, significant economic benefits would flow to residents region-wide, even if low-income residents were displaced. Certainly, in that case there would be important questions about how those benefits would be distributed. But, however, they are distributed, if SLU residents choose to prevent displacement in such a way as to undercut the boom, there is no guarantee that democracy or social justice would be served. While the needs of Cascade residents would be met, they might prevent the creation of wellpaying jobs that could benefit people across the region. In that case, the interests of a neighbourhood-level low-income population would be privileged over the needs of a much larger regional low-income population. ${ }^{3}$ The decision-making structure could be said to be closer to oligarchy than democracy, as a small cadre of individuals makes a decision that serves their interests but not the interests of a larger public.

Alternatively, it is entirely possible (or even probable) that the promise of biotechnology is being overstated, that the proposed redevelopment would have little economic impact and only succeed in displacing lowincome residents and enriching Paul Allen. In that case, local neighbourhood control could oppose redevelopment, prevent gentrification and avoid wasting a large public investment. The needs of both the neighbourhood inhabitants and citizens across the city would be met. A just outcome would result, but it would still not be the most democratic decision-making process.
Therefore, the same structure of local control could produce both just and unjust outcomes, depending on the unknown effects of biotechnology development. Localising decision-making authority would empower the agenda of Cascade neighbourhood inhabitants. In the case of SLU, that would mean an anti-gentrification agenda. The needs of the local population would certainly be met. The needs of the regional population may or may not be met. If the promise of a biotechnology boom is a chimera, localisation would empower an agenda of social justice without democratisation. In a different empirical context, localisation might not achieve social justice, as when wealthy home-owners use local control to prevent new low-income housing rather than preserving it. And localisation could lead to democratisation as well, if, for example, neighbourhood inhabitants gained greater say over the development of a small strip mall that primarily served neighbourhood residents. In the latter case, the interests of the larger population would be minimal and local control would not privilege a local community over larger communities. In the SLU case, while localisation would tend away from democratisation (in the sense of whether the entire affected population has a say in the decision), it is very difficult to predict whether or not it would produce more social justice. The local trap assumes that localisation is desirable, but the situation is quite a lot more complicated than that.

While the right to the city makes the local trap tempting, there is another way to imagine the right to the city in the SLU case that would rely less heavily on scalar assumptions. Groups of neighbourhood inhabitants across the city could oppose the redevelopment based on the massive amounts of public investment it is likely to involve. Here, the argument is that public money, especially that being spent by the City, is flowing into one neighbourhood rather than being distributed more fairly throughout Seattle. It is being used to promote economic growth rather than the use-value of Seattle inhabitants. The right to the city would 
argue that public investment should flow to areas where inhabitants' use-value needs are greatest, not where economic growth potential is highest. People in neighbourhoods like Columbia City and Rainier Beach have argued that they have long-standing infrastructure needs (streets, sidewalks, parks) that the City has ignored, and yet it is committing huge amounts to redevelop South Lake Union. Moreover, that investment is not likely to meet the use-value needs of SLU inhabitants, but benefit the exchange value interests of private firms. The right to the city would argue that such public investment should benefit those who inhabit the city, not those who own its property. Under this banner, neighbourhood groups across the city might join in what Laclau and Mouffe (1985) call a 'chain of equivalence', where diverse political groups coalesce around a shared political interest. Using the right to the city as the basis of their claim, they could press the city to involve inhabitants directly in decisions on how to spend public money, so that a use-value agenda could be most fully advanced. A viable movement has not yet developed along these lines, but the sentiment, and therefore political potential, is there.

Such a movement would avoid the local trap because it would not be concerned with a scalar approach to decision-making. It would still draw on Lefebvre's notion of inhabitance, arguing that the needs of property owners should be counterbalanced by the needs of inhabitants across the city. But it would not assume the needs of local Cascade inhabitants to be more important than the needs of inhabitants in other neighbourhoods or inhabitants at other scales. It would stress the political distinction between inhabitant and owner, not the scalar distinction between the local and wider scales. As this second conception makes clear, the right to the city does not lead inevitably into the local trap, rather it only tempts one in that direction. It could also inspire effective resistance to neo-liberal urbanism, but only if we insist that there is nothing inherent about scale.

\section{Conclusion}

The SLU case study involves an interplay between neighbourhood, municipal and regional scales. In this case, the local scale means the neighbourhood scale. Of course, the same dynamic applies when we consider the right to the city in a wider scalar context. The entire urban region can also be the relatively more local scale. For example, the Port of Seattle affects Seattle-area inhabitants, but it is also critical for rural communities across the Pacific Northwest, who use it to ship agricultural products. The right to the city would urge us to consider first what is best for the urban inhabitants who experience the Port in the course of their daily routines. However, in decisions about the Port, if we favour urban inhabitants over state-wide inhabitants, we are just as likely to diminish democracy as we are to enhance it. Thus, the specific notion of the right to the city can be dangerous because it can impel us to prefer a priori the urban scale over wider scales-a preference that is the essence of the local trap. It therefore makes sense to talk instead of the right to inhabit, without reference to the scale or settlement pattern one inhabits. The essence of Lefebvre's vision is to favour those who inhabit space over those who own it. It is not to favour local inhabitants over inhabitants at wider scales or, I would argue, to favour urban inhabitants over rural ones. The right to the city in particular leads easily to a privileging of the local urban scale and thus into the local trap. In using Lefebvre's ideas to help us to imagine new forms of democracy, it is critical not to privilege the urban-as a scale-a priori.

This same logic also applies to the idea of urban democracy more generally. There is nothing inherently important about the urban scale in creating a more democratic society. Rather, any talk of reinvigorating urban democracy might be better expressed as reinvigorating democracy in cities. Because the neo-liberal agenda has been pursued particularly vehemently in cities, there is a particular strategic, though contingent, need to invent radical democratic practices in cities 
(Brenner and Theodore, 2002). That does not mean the urban is inherently more important than wider scales (or non-urban places), only that it is perhaps a more strategic front at this particular time and place. Equally important in the long term is to resist neoliberalism by developing radical democratic resistance at broader scales and in rural places. The right to inhabit, freed of an overemphasis on the urban, is a promising principle that can inspire that resistance.

\section{Notes}

1. This trend can be seen as largely the result of the on-going regulation of neo-liberalism in cities. That is, as raw neo-liberalism creates social discord, inequality and legitimacy problems, it becomes necessary to develop regulatory mechanisms that can manage these problems (Tickell and Peck, 2003). For example, I would argue that the meteoric rise of deliberative practices in planning (often called 'communicative planning'), are in part a way to create a visible process whose rules are democratic enough to legitimate decisions but still ensure a controlling interest for capital.

2. It is worth noting other scalar traps on the left as well, as with the argument that global neoliberalism is best countered by a similarly global strategy of resistance (Hardt and Negri, 2000). Similarly, socialists and social democrats commonly call for re-empowering the national state as the best hope for the resurrection of strong policies of social provision and income redistribution. And many urban scholars call for regional governance as the best hope for challenging inequality within the metropolitan region (for example, Rusk, 1995).

3. To complicate the evaluation further, on a global scale, Seattle is a relatively affluent city. If it successfully attracts biotech investment (instead of, say, Bangalore) whatever wealth is captured locally would tend to exacerbate inequality on a global scale.

\section{References}

Agnew, J. (1997) The dramaturgy of horizons: geographical scale in the 'reconstruction of Italy' by the new Italian political parties, 199295, Political Geography, 16(2), pp. 99-121.

Aigner, S., Flora, C. ET AL. (2001) The premise and promise of citizenship and civil society for renewing democracies and empowering sustainable communities, Sociological Inquiry, 71(4), pp. 493-508.

Amin, A. and Thrift, N. (2002) Cities: Reimagining the Urban. Cambridge: Polity Press.

Axtman, R. (1996) Liberal Democracy into the Twenty-first Century: Globalization, Integration and the Nation-state. Manchester: Manchester University Press.

BAIOCCHI, G. (2003) Participation activism and politics: the Porto Alegre experiment, in: A. Fung and E. Wright (Eds) Deepening Democracy, pp. 45-76. New York: Verso.

Barber, B. (2004) Strong Democracy. Berkeley, CA: University of California Press.

Beauregard, R. and Bounds, A. (2000) Urban citizenship, in: E. Isin (Ed.) Democracy, Citizenship and the Global City, pp. 243-256. New York: Routledge.

BENDER, T. (1999) Intellectuals, cities, and citizenship in the United States: the 1890s and 1990s, in: J. Holston (Ed.) Cities and Citizenship, pp. 21-41. Durham, NC: Duke University Press.

Benhabib, S. (1996) Toward a deliberative model of democratic legitimacy, in: S. BEnhabiB (Ed.) Democracy and Difference: Contesting Boundaries of the Political, pp. 67-94. Princeton, NJ: Princeton University Press.

Berry, J., Portney, K. et AL. (1993) The Rebirth of Urban Democracy. Washington, DC: Brookings Institution.

Born, B. and Purcell, M. (forthcoming) Avoiding the local trap: scale and food systems in planning research, Journal of Planning Education and Research.

Boudreau, J. (2003) Questioning the use of 'local democracy' as a discursive strategy for political mobilization in Los Angeles, Montreal and Toronto, International Journal of Urban and Regional Research, 27(4), pp. 793-811.

BRENNER, N. (1999) Globalisation as reterritorialisation: the rescaling of urban governance in the European Union, Urban Studies, 36(3), pp. 431-451.

Brenner, N. (2001) The limits to scale? Methodological reflections on scalar structuration, Progress in Human Geography, 25(4), pp. 591-614.

Brenner, N. and Theodore, N. (2002) Cities and the geographies of 'actually existing neoliberalism', Antipode, 34(3), pp. 349-379.

Brodie, J. (2000) Imagining democratic urban citizenship, in: E. IsIN (Ed.) Democracy, Citizenship and the Global City, pp. 110-128. New York: Routledge.

Brown, C. and Purcell, M. (2005) There's nothing inherent about scale: political ecology, the local trap, and the politics of development 
in the Brazilian Amazon, Geoforum, 36, pp. 607-624.

Brown, M. (1997) Replacing Citizenship: AIDS Activism and Radical Democracy. New York: Guilford Press.

Brownhill, S., Razzaque, K. ET AL. (1996) Local governance and the racialisation of urban policy in the UK: the case of urban development corporations, Urban Studies, 33, pp. 1337-1355.

BuRONI, T. (1998) A case for the right to habitat. Paper prepared for the Seminar on Urban Poverty, Rio de Janeiro.

Castles, S. (2001) Globalization and citizenship: an Australian dilemma, Patterns of Prejudice, 35(1), pp. 91-109.

Ceraso, K. (1999) Seattle neighborhood planning. Shelterforce Online, 108.

Chaskin, R. and Abunimah, A. (1999) A view from the city: local government perspectives on neighborhood-based governance in community-building initiatives, Journal of Urban Affairs, 21(1), pp. 57-78.

Cities for Human Rights (1998) Barcelona, October.

City \& Shelter ET AL. (n.d.) The European charter for women in the city. Equal Opportunities Unit, Commission of the European Union, Brussels.

CoHen, J. and Rogers, J. (1995) Associations and Democracy. London: Verso.

Council of Europe (1985) European Charter of local self-government (http://conventions.coe. int/treaty/en/treaties/html/122.htm).

Cunningham, F. (2001) Theories of Democracy. New York: Routledge.

DANIEL, C. (2001) Participatory urban governance: the experience of Santo Andre, United Nations Chronicle Online, 38(1).

DEAS, I. and WARD, K. (2000) From the 'new localism' to the 'new regionalism'? The implications of regional development agencies for city-regional relations, Political Geography, 19(3), pp. 273-292.

DECKER, F. (2002) Governance beyond the nationstate: reflections on the democratic deficit of the European Union, Journal of European Public Policy, 9(2), pp. 256-272.

Delaney, D. and LeITNER, H. (1997) The political construction of scale, Political Geography, 16(2), pp. 93-97.

DiERs, J. (2004) Neighbor Power: Building Community the Seattle Way. Seattle: University of Washington Press.

DikeC, M. (2001) Justice and the spatial imagination, Environment and Planning A, 33, pp. 1785-1805.

DryzeK, J. (1996) Democracy in Capitalist Times. Oxford: Oxford University Press.
Fainstein, S. and Fainstein, N. (1995) A proposal for urban policy in the 1990s, Urban Affairs Review, 30(5), pp. 630-635.

FALK, R. (2000) The decline of citizenship in an era of globalization, Citizenship Studies, 4(1), pp. 5-18.

FlyvbJerg, B. (1998) Rationality and Power: Democracy in Practice. Chicago, IL: University of Chicago Press.

Friedmann, J. (1995) The right to the city, Society and Nature, 1(1), pp. 71-84.

FRIEDMANN, J. (2002) City of fear or open city?, Journal of the American Planning Association, 68(3), pp. 237-243.

Fung, A. (2004) Empowered Participation: Reinventing Urban Democracy. Princeton, NJ: Princeton University Press.

Fung, A. and Wright, E. (Eds) (2003a) Deepening Democracy: Institutional Innovations in Empowered Participatory Governance. New York: Verso.

Fung, A. and Wright, E. (2003b) Thinking about empowered participatory governance, in: A. Fung and E. Wright (Eds) Deepening Democracy: Institutional Innovations in Empowered Participatory Governance, pp. 342. New York: Verso.

GILL, S. (1996) Globalization, democratization, and the politics of indifference, in: J. MITTELMAN (Ed.) Globalization: Critical Reflections, pp. 205-228. Boulder, CO: Lynne Rienner.

Gittell, M., Ortega-Bustamante, I. ET $A L$. (2000) Social capital and social change: women's community activism, Urban Affairs Review, 36(2), pp. 123-148.

Goodhart, M. (2001) Democracy, globalization, and the problem of the state, Polity, 33(4), pp. 527-546.

Goodman, D. (2003) The quality 'turn' and alternative food practices: reflections and agenda, Journal of Rural Studies, 19(1), pp. 1-7.

GougH, J. (2002) Neoliberalism and socialisation in the contemporary city: opposites, complements and instabilities, Antipode, 34(3), pp. 405-426.

Grant Building Tenants Association (2001) Grant building saved (for the moment)! Grant Building Tenants Association, San Francisco, CA.

Green, G. and Haines, A. (2001) Asset Building and Community Development. Thousand Oaks, CA: Sage.

GREENBERG, M. (1999) Restoring America's Neighborhoods: How Local People Make a Difference. New Brunswick, NJ: Rutgers University Press.

Hambleton, R., Savitch, H. ET AL. (Eds) (2003) Globalism and Local Democracy: Challenge and Change in Europe and North America. New York: Palgrave Macmillan. 
Hammar, T. (1990) Democracy and the Nation State: Aliens, Denizens, and Citizens in a World of International Migration. Brookfield, VT: Gower Publishing Co. Ltd.

HARdt, M. and Negri, A. (2000) Empire. Cambridge, MA: Harvard University Press.

Harvey, D. (1982) The Limits to Capital. Oxford: Blackwell.

Hasselhoff, K. (2002) Motivations for the San Fernando Valley secession movement: the political dynamics of secession, Journal of Urban Affairs, 24(4), pp. 425-443.

Held, D. (1995) Democracy and the Global Order. Cambridge: Polity.

Herbert, S. (2005) The trapdoor of community, Annals of the Association of American Geographers, 95(4), pp. 850-865.

Hipsher, P. (1996) Democratization and the decline of urban social movements in Chile and Spain, Comparative Politics, 28(3), pp. 273-297.

Hoggett, P. (1987) A farewell to mass production? Decentralization as an emergent private and public sector paradigm, in: P. Hoggett and R. Hambleton Decentralization and democracy: localizing public services. School for Advanced Urban Studies, Bristol.

Holston, J. (1999) Spaces of insurgent citizenship, in: J. Holston (Ed.) Cities and Citizenship, pp. 155-173. Durham, NC: Duke University Press.

Holston, J. and Appadurai, A. (1999) Introduction: cities and citizenship, in: J. Holston (Ed.) Cities and Citizenship, pp. 1-20. Durham, NC: Duke University Press.

HowitT, R. (1998) Scale as relation: musical metaphors of geographical scale, Area, 30(1), pp. 49-58.

IsIN, E. (1996) Global city-regions and citizenship, in: R. KeIl, G. WeKerle and D. Bell (Eds) Local Places in the Age of the Global City, pp. 21-36. New York: Black Rose Books.

Isin, E. (Ed.) (2000a) Democracy, Citizenship and the Global City. New York: Routledge.

IsIN, E. (2000b) Governing cities without government, in: E. IsIN (Ed.) Democracy, Citizenship and the Global City, pp. 148-168. New York: Routledge.

Isin, E. and Wood, P. (1999) Citizenship and Identity. Thousand Oaks, CA: Sage.

JEssop, B. (1997) A neo-Gramscian approach to the regulation of urban regimes: accumulation strategies, hegemonic projects, and governance, in: M. LAURIA (Ed.) Reconstructing Urban Regime Theory: Regulating Urban Politics in a Global Economy, pp. 51-73. Thousand Oaks, CA: Sage.

JEssop, B. (2002) Liberalism, neoliberalism, and urban governance: a state-theoretical perspective, Antipode, 34(3), pp. 452-472.
Jones, M. and WARD, K. (2002) Excavating the logic of British urban policy: neoliberalism as the 'crisis of crisis-management', Antipode, 34(3), pp. 473-494.

Keating, M. (1991) Local development politics in Britain and France, Journal of Urban Affairs, 13, pp. 443-459.

KeIL, R. (2002) 'Common-sense' neoliberalism: progressive conservative urbanism in Toronto, Canada, Antipode, 34(3), pp. 578-601.

Kelly, P. (1997) Globalization, power and the politics of scale in the Philippines, Geoforum, 28(2), pp. 151-171.

Kelly, P. (1999) The geographies and politics of globalization, Progress in Human Geography, 23(3), pp. 379-400.

KIPFER, S. and KeIL, R. (2002) Toronto Inc? Planning the competitive city in the new Toronto, Antipode, 34(2), pp. 227-264.

KofmAn, E. and LeBAs, E. (1996) Lost in transposition: time, space, and the city, in: $\mathrm{E}$. KofmAn and E. LEBAS (Eds) Writings on Cities, pp. 3-60. Cambridge, MA: Blackwell.

LAClAu, E. and MoufFe, C. (1985) Hegemony and Socialist Strategy: Towards a Radical Democratic Politics. London: Verso.

LARNER, W. (2005) Co-constituting 'after neoliberalism': new forms of governance in Aotearoa New Zealand. Paper presented at the conference Towards a Political Economy of Scale, York University, Toronto, February.

LATENDRESSE, A. (2004) Democracy in Montreal: one step forward, two steps back, Canadian Dimension, 38(5), pp. 39-40.

Lefebvre, H. (1968) Le droit à la ville. Paris: Anthopos.

Lefebvre, H. (1973) Espace et politique. Paris: Anthropos.

Lefebvre, H. (1991a) The Production of Space. Oxford: Blackwell.

LEFEBVRE, H. (1991b) Les illusions de la modernité, Manières de voir, 13, pp. 14-17.

LeFEBVRE, H. (1996) Writings on Cities. Cambridge, MA: Blackwell.

Lefebvre, H. (2003) The Urban Revolution. Minneapolis, MN: University of Minnesota Press.

LeITNER, H. and ShePpARD, E. (2002) 'The city is dead, long live the net': harnessing European interurban networks for a neoliberal agenda, Antipode, 34(3), pp. 495-518.

Linklater, A. (1998) Cosmopolitan citizenship, Citizenship Studies, 2(1), pp. 23-41.

Lummis, C. (1997) Radical Democracy. Ithaca, NY: Cornell University Press.

MACLEOD, G. (2002) From urban entrepreneurialism to a revanchist city? On the spatial inhjustices of Glasgow's renaissance, Antipode, 34(3), pp. 602-624. 
MACLEOD, G. and Goodwin, M. (1999) Reconstructing an urban and regional political economy: on the state, politics, scale, and explanation, Political Geography, 18(6), pp. 697-730.

Madon, S. and Sahay, S. (2000) Democracy and information: a case study of new local governance structures in Bangalore, Information, Communication, and Society, 3(2), pp. 173192.

MANsbridge, J. (1983) Beyond Adversary Democracy. Chicago, IL: University of Chicago Press.

MARston, S. (2000) The social construction of scale, Progress in Human Geography, 24(2), pp. 219-242.

Matthews, J. (1989) Age of Democracy: The Political Economy of Post-Fordism. New York: Oxford University Press.

McGuIRK, P. (2001) Situating communicative planning theory: context, power, and knowledge, Environment and Planning A, 33, pp. 195-217.

MCNulty, R. (1999) Community empowerment manual. Partners for Livable Communities, Washington, DC.

Mesch, G. and Schwirian, K. (1996) The effectiveness of neighborhood collective action, Social Problems, 43(4), pp. 467-484.

Mitchell, D. (2003) The Right to the City: Social Justice and the Fight for Public Space. New York: Guilford Press.

Mitchell, K. (2001) Education for democratic citizenship: transnationalism, multiculturalism, and the limits of liberalism, Harvard Educational Review, 71(1), pp. 51-78.

Mohan, G. and Stokke, K. (2000) Participatory development and empowerment: the dangers of localism, Third World Quarterly, 21(2), pp. 247-268.

Mouffe, C. (1999) Deliberative democracy or agonistic pluralism?, Social Research, 66(3), pp. 745-758.

Mulady, K. (2004a) City's ties to Vulcan run deep, Seattle Post-Intelligencer, 25 October, p. A14.

Mulady, K. (2004b) Remaking South Lake Union: Seattle is on fast track to build biotech hub, Seattle Post-Intelligencer, 20 October, p. A1.

MurPhy, C. (2000) Global governance: poorly done and poorly understood, International Affairs, 76(4), pp. 789-803.

Murphy, P. and Cunningham, J. (2003) Organizing for Community Controlled Development: Renewing Civil Society. Thousand Oaks, CA: Sage.

NyLEN, W. (2003) Participatory Democracy versus Elitist Democracy: Lessons from Brazil. New York: Palgrave Macmillan.
OLDS, K. (1998) Urban mega-events, evictions and housing rights: the Canadian case, Current Issues in Tourism, 1(1), pp. 2-46.

Parker, W. (2003) Teaching Democracy: Unity and Diversity in Public Life. New York: Teachers College Press.

Pateman, C. (1970) Participation and Democratic Theory. Cambridge: Cambridge University Press.

PECK, J. (1998) Geographies of governance: TECs and the neo-liberalisation of 'local interests', Space \& Polity, 2(1), pp. 5-31.

PECK, J. (2001) Workfare States. New York: Guilford Press.

Peterman, W. (1999) Neighborhood Planning and Community-based Development: The Potential and Limits of Grassroots Action. Thousand Oaks, CA: Sage.

Pratchett, L. (1999) Renewing Local Democracy? The Modernisation Agenda in British Local Government. London: Frank Cass.

Pratchett, L. (2004) Local autonomy, local democracy and the 'new localism', Political Studies, 52, pp. 358-375.

Purcell, M. (2000) The decline of the political consensus for growth: evidence from Los Angeles, Journal of Urban Affairs, 22(1), pp. $85-100$.

PURCELL, M. (2002) Excavating Lefebvre: the right to the city and its urban politics of the inhabitant, GeoJournal, 58(2/3), pp. 99-108.

Purcell, M. (2003) Citizenship and the right to the global city: reimagining the capitalist world order, International Journal of Urban and Regional Research, 27(3), pp. 564-590.

PurCell, M. (2004) City-regions, neoliberal globalization, and democracy: a research agenda. Paper presented at the 30th Congress of the International Geographical Union, Glasgow, August.

Purcell, M. and Brown, J. (2005) Against the local trap: scale and the study of environment and development, Progress in Development Studies, 5(4), pp. 279-297.

Putnam, R. (1993) Making Democracy Work: Civic Traditions in Modern Italy. Princeton, NJ: Princeton University Press.

Rights to the City (1998) Conference held at York University, Toronto, June.

Rights to the City (2002) Conference held in Rome, May.

Rusk, D. (1995) Cities without Suburbs. Washington, DC: Woodrow Wilson Center Press.

SANDERCOCK, L. (1998) The death of modernist planning: radical praxis for a postmodern age, in: J. FriedmanN and M. Douglass (Eds) Cities for Citizens: Planning and the Rise of Civil Society in a Global Age, pp. 163-184. New York: John Wiley \& Sons. 
Sassen, S. (2000) The global city: strategic site/ new frontier, in: E. IsIN (Ed.) Democracy, Citizenship and the Global City, pp. 48-61. New York: Routledge.

ScotT, A. (1993) Technopolis: High-technology Industry and Regional Development in Southern California. Los Angeles, CA: University of California Press.

SeCOR, A. (2003) Citizenship in the city: identity, community, and rights among women migrants to Istanbul, Urban Geography, 24(2), pp. 147168.

Smith, N. (1992) Geography, difference and the politics of scale, in: J. Doherty, E. Graham and M. MALEK (Eds) Postmodernism and the Social Sciences, pp. 57-79. London: Macmillan.

Sмiтн, N. (1993) Homeless/global: scaling places, in: J. BIRD (Ed.) Mapping the Futures: Local Cultures Global Change, pp. 87-119. New York: Routledge.

Sмith, N. (2002) New globalism, new urbanism: gentrification as global urban strategy, Antipode, 34(3), pp. 427-450.

Smith, S. (1995) Citizenship: all or nothing?, Political Geography, 14(2), pp. 190-193.

Sмоск, K. (2003) Democracy in Action: Community Organizing and Urban Change. New York: Columbia University Press.

SoJA, E. (1996) Thirdspace: Journeys to Los Angeles and Other Real-and-imagined Places. Cambridge, MA: Blackwell.

SoJA, E. (2000) Postmetropolis. Malden, MA: Blackwell.

SouzA, M. (2001) The Brazilian way of conquering the 'right to the city', DISP, 147, pp. $25-31$.

SoYSAL, Y. (1999) Toward a postnational model of citizenship, in: G. SHAFIR (Ed.) The Citizenship Debates, pp. 189-217. Minneapolis, MN: University of Minnesota Press.

Speller, G. and RAVEnscroft, N. (2005) Facilitating and evaluating public participation in urban parks management, Local Environment, 10(1), pp. 41-57.

Staeheli, L. (1994) Restructuring citizenship in Pueblo, Colorado, Environment and Planning A, 26(6), pp. 849-871.

Staeheli, L. (2003) Cities and citizenship, Urban Geography, 24(2), pp. 97-103.

SwyngEDOUw, E. (1997a) Excluding the other: the production of scale and scaled politics, in: R. LEE and J. WiLls (Eds) Geographies of Economies, pp. 167-176. London: Arnold.
Swyngedouw, E. (1997b) Neither global nor local: 'glocalization' and the politics of scale, in: K. Cox (Ed.) Spaces of Globalization, pp. 137-166. New York: Guilford Press.

Swyngedouw, E. (2000) Authoritarian governance, power, and the politics of rescaling, Environment and Planning D, 18(1), pp. 63-76.

Swyngedouw, E., Moulaert, F. ET al. (2002) Neoliberal urbanization in Europe: large-scale urban development projects and the new urban policy, Antipode, 34(3), pp. 542-577.

Tickell, A. and Peck, J. (2003) Making global rules: globalisation or neoliberalisation?, in: J. Peck and H. Yeung (Eds) Remaking the Global Economy: Economic-geographical Perspectives, pp. 163-182. London: Sage.

Turner, B. (2000) Cosmopolitan virtue: loyalty and the city, in: E. IsIN (Ed.) Democracy, Citizenship and the Global City, pp. 129-147. New York: Routledge.

UNCHS (United Nations Centre for Human Settlements) (2001) Policy dialogue series: No. 1 Women and urban governance. UNCHS (Habitat), New York.

UNDESA (United Nations Department of ECONOMIC AND SOCIAL AFFAIRS) (1992) Report of the United Nations Conference on Environment and Development. United Nations, Rio.

WARD, K. (2000) A critique in search of a corpus: re-visiting governance and re-interpreting urban politics, Transactions of the Institute of British Geographers, 25(2), pp. 169-185.

Weir, S. and Beetham, D. (1999) Political Power and Democratic Control in Britain. London: Routledge.

Wells, V. (2002) Mississippi milestones: developing a comprehensive plan for a city by starting at the grass roots level isn't a new idea, Planning, 68(8), pp. 24-28.

Worldwide Conference on the Right to Cities Free from Discrimination and Inequality (2002) Porto Allege, Brazil, February.

Wu, F. (2002) China's changing urban governance in the transition towards a more market-oriented economy, Urban Studies, 39(7), pp. 1071-1093.

Yaghmaian, B. (1998) Globalization and the state: the political economy of global accumulation and its emerging mode of regulation, Science and Society, 62(2), pp. 241-265.

Young, I. (2000) Inclusion and Democracy. New York: Oxford University Press.

Yuval-Davis, N. (1997) Women, citizenship and difference, Feminist Review 57, pp. 4-28. 